\title{
Relationships between some Quantitative Characters in Selected Cowpea Germplasm [(Vigna unguiculata L. (Walp)]
}

\author{
Muhammad Lawan UMAR ${ }^{1)}$, Mohammed G. SANUSI'), Fagwalawa D. LAWAN ${ }^{3)}$ \\ 1) Ahmadu Bello University, Faculty of Agriculture, Department of Plant Science, Zaria, Nigeria; mahammadlawan@yahoo.com \\ 2) Bayero University, Faculty of Agriculture, Department of Agronomy, Kano, Nigeria; sgmohammed@yahoo.com \\ 3) University of Science and Technology, Department of Biology Sciences, Wudil, Kano, Nigeria
}

\begin{abstract}
The morphotypic variations of eight local varieties ('Achishiru', 'Aloka local,' 'Borno local,' 'Danila,' 'Danmisira,' 'Danwuri, 'Kanannado' and 'Yambare') of cowpea [Vigna unguiculata L. (Walp)] were studied in relation to their yield in 2004 rainy season. Simple correlation coefficients among the different pairs of variables were computed using mean values for each variable. The genotypic $\left(r_{\mathrm{g}}\right)$, phenotypic $\left(r_{p}\right)$ and environmental $\left(r_{e}\right)$ correlation coefficients were estimated. The magnitude of the genotypic correlation coefficients were in most cases higher than their corresponding phenotypic $\left(r_{p}\right)$ and environmental $\left(r_{e}\right)$ correlation coefficients. High and positive $r_{g}$ exists between days to $50 \%$ flowering and plant height $\left(\mathrm{r}_{\mathrm{g}}=0.9113\right)$, days to maturity and fodder weight $\left(\mathrm{r}_{\mathrm{g}}=0.9301\right)$, days to maturity and 100 seed weight $\left(r_{g}=0.6958\right)$ and number of leaves per plant and fodder weight $\left(r_{g}=0.8096\right)$. On the other hand, high but negative $r_{g}$ exists between plant height and pod per plant $\left(\mathrm{r}_{\mathrm{g}}=-0.6011\right)$. Also, the relationship between days to maturity, and number of seed per pod were all negative and moderate.
\end{abstract}

Keywords: morphotypic, cowpea, Vigna unguiculata, germplasm

\section{Introduction}

Cowpea [Vigna unguiculata (L) Walp] is considered as the most important legume in west Africa primarily grown in areas where the minimum and maximum temperatures range between $20{ }^{\circ} \mathrm{C}$ and $35^{\circ} \mathrm{C}$, respectively during the growing season. Cowpea grows in a wide range of environments covering $40^{\circ} \mathrm{N}$ to $30^{\circ} \mathrm{S}$ (Rachie, 1985).

Cowpea is a cheap source of protein (20-26\%) and starch (50-67\%) (Singh et al., 1997). The leaves, stems and seeds have antimicrobial properties that frequent consumers had lower blood pressures (BP) and total serum cholesterol levels. Consequently, consumers were less likely to be diagnosed with high BP, diabetes and other heart diseases (Brazzino, 2002). In Nigeria, the varieties under cultivation are unimproved, local types which are photoperiod sensitive when planted in the normal planting (rainy) season (June-July), which coincides with long days. When planted in the dry season with irrigation they mature within 60-80 days but remain stunted in growth under low temperature conditions (Mukhtar and Singh, 2006) resulting in poor fodder yields.

Cowpea growth habit ranges from erect, semi-erect, spreading to climbing and trailing types (Steele, 1976) with plant height varying from dwarf (about $15 \mathrm{~cm}$ ) to tall (over $100 \mathrm{~cm}$ ). Seeds have various colours (brown, white and speckled), different seed shapes (kidney, void and rhomboid) and sizes as described by Martin et al. (1976).
The study of relationships among quantitative traits is important for assessing the feasibility of joint selection of two or more traits and hence for evaluating the effect of selection for secondary traits on genetic gain for the primary trait under consideration. A positive genetic correlation between two desirable traits makes selection easy for improving both traits simultaneously. A negative correlation between two desirable traits makes it impossible to achieve significant improvement in both traits. However, simple correlations do not give a better perspective into the true biological relationships of these traits with yield; being quantitative in nature, is a complex trait with low heritability and depends upon several other components with high heritability (Ezeaku and Mohammed, 2006).

In view of the above, this research is aimed at careful observations of the relationships existing between quantitative characters of the selected varieties and also pave way to find which variety is adapted to this kind of planting season. The investigation of the quantitative characters will also elucidate areas needing attention to make improvement on the growth habit and better adaptation to seasonal variation.

\section{Materials and methods}

The study was conducted at the Research Farm and Botanic Garden of the Department of Biological Science, Bayero University, Kano, Nigeria (latitude 11 ${ }^{0} 55^{\prime} \mathrm{N}$ and 
126

longitude $\left.8^{0} 28^{\prime} \mathrm{E}\right)$. The area falls within the Sudan savannah agroecological zone (Olofin, 1987) characterized by two seasons: the rainy season with long day length, usually begins from May and ends in September with heavier rainfalls in July and August. The dry season is characterized by short day length which begins in October and ends in April/May (Singh, 1992). Total mean rainfall during the period of the study was $756 \mathrm{~mm}$, while the average minimum and maximum temperatures were $22{ }^{\circ} \mathrm{C}$ and 34.8 ${ }^{0} \mathrm{C}$, respectively. The minimum and maximum relative humidity recorded in the same period were 33.1 and $56.0 \%$, respectively. The treatments consisted of eight cowpea varieties planted in a completely randomized block design with four replications. The experimental unit was four row plot of $5 \mathrm{~m}$ long spaced at $0.75 \mathrm{~m}$ apart with a plantto-plant spacing of $0.4 \mathrm{~m}$. Seedlings were thinned to two plants per stand at 14 days after planting. Cypercott containing cypermethrin $10 \% \mathrm{EC}$ ) was sprayed at the rate of 1litre/ha at vegetative, flowering and podding stages to protect the crop against the menace of insect pests prevalent in the area.

Five plants each from the two middle rows of each plot were randomly selected for recording days to $50 \%$ flowering, plant height, number of leaves per plant, and days to maturity. The border rows were used for estimating leaf area, root length and number of root nodules per plant.

The data obtained were statistically analysed based on Steele and Torrie (1981) procedure and correlation coefficients were computed from variance and covariance components using the formula described by Singh and Chaudhary (1985) where:

$$
\mathrm{r}_{\left(X_{1} X_{2}\right)}=\frac{\operatorname{Cov}_{\left(X_{1} X_{2}\right)}}{\sqrt{\sigma_{\left(X_{1}\right)}{ }^{*} \sigma_{\left(X_{2}\right)}}}
$$

Where: $r\left(X_{1} X_{2}\right)$ is the correlation between $X_{1}$ and $X_{2}$ $\operatorname{Cov}\left(\mathrm{X}_{1} \mathrm{X}_{2}\right)$ is the covariance between $\mathrm{X}_{1}$ and $\mathrm{X}_{2}$

$\mathrm{V}\left(\mathrm{X}_{1}\right)$ is the variance for $\mathrm{X}_{1}$

$\mathrm{V}\left(\mathrm{X}_{2}\right)$ is the variance for $\mathrm{X}_{2}$

\section{Results and discussion}

Tab. 1. Mean values for growth and yield parameters in cowpea.

\begin{tabular}{ccccccccc}
\hline Varieties & $\begin{array}{c}\text { Days to 50\% } \\
\text { flowering }\end{array}$ & $\begin{array}{c}\text { Days to } \\
\text { maturity }\end{array}$ & $\begin{array}{c}\text { Plant height } \\
(\mathrm{cm})\end{array}$ & $\begin{array}{c}\text { Number of } \\
\text { leaves plant }\end{array}$ & $\begin{array}{c}\text { Fodder } \\
\text { weight }(\mathrm{g})\end{array}$ & $\begin{array}{c}\text { Number of } \\
\text { pod plant }^{-1}\end{array}$ & $\begin{array}{c}100 \text { seed } \\
\text { weight }(\mathrm{g})\end{array}$ \\
\hline 'Achishiru' & 41 & 69 & 85.8 & 38 & 31.3 & 15 & 8.7 \\
\hline 'Aloka local' & 52 & 80 & 114.3 & 37 & 47.4 & 11 & 14.0 \\
\hline 'Borno local' & 60 & 84 & 96.3 & 122 & 75.6 & 6 & 11.2 \\
\hline 'Danila' & 56 & 84 & 123.3 & 108 & 91.5 & 12 & 14.9 \\
\hline Danmisira & 68 & 86 & 121.6 & 125 & 125.2 & 8 & 18. \\
\hline 'Danwur' & 46 & 74 & 70.2 & 38 & 72.2 & 13 & 13.3 \\
'Kanannado' & 85 & 113 & 153.6 & 141 & 151.4 & 5 & 17.1 \\
\hline 'Yambare' & 67 & 89 & 147.9 & 157 & 102.0 & 16 & 15.3 \\
\hline Mean & 59 & 84.9 & 114.1 & 95.6 & 87.1 & 10.7 & 10.7 \\
\hline C.V. $(\%)$ & 4.3 & 12.1 & 19.1 & 6.7 & 10.7 & 11.16 & 5.5 \\
\hline
\end{tabular}

The results of the growth and yield characters studied in this work were presented in Tab. 1. It shows that varieties like 'Kanannado' that matured late (113 DAP) tend to produced longer stem height $(153.6 \mathrm{~cm})$ with least pod per plant ( 5 pod/plant), while 'Achishiru' matured earliest (85 DAP) but produced the highest number of pods per plant (15 pod/plant) but the least fodder $(31.3 \mathrm{~g})$. This might be accorded to the differences in response to photosensitivity, which the varieties exhibited greatly.

The correlation coefficients were partitioned into genotypic $\left(r_{g}\right)$, phenotypic $\left(r_{p}\right)$ and environmental $\left(r_{e}\right)$ sources between growth and yield components and presented in Tab. 2. The magnitude of genotypic correlation coefficients were in most cases higher than their corresponding phenotypic $\left(r_{p}\right)$ and environmental $\left(r_{e}\right)$ correlation coefficients indicating inherent relationship between most of the traits studied as suggested by Khairwal et al. (1999).

The implication of high positive genotypic correlation observed between days to $50 \%$ flowering and plant height $\left(r_{g}=0.9113\right)$ and days to maturity and fodder weight $\left(r_{\mathrm{g}}=0.8872\right)$ is that, late flowering varieties tend to produce numerous and longer branches, mature late and produced high amount of fodder as exhibited by 'Kanannado', 'Yambare' and' Danmisira'. On the other hand, the early maturing varieties ('Achishiru' and 'Danwuri') produced few short branches, matured early and produced the least fodder. This might be due to the differences in response to photosensitivity shown by the different varieties. The longer the reproductive period, the greater the number of leaves, stem height and the higher the amount of fodder to expected from a variety (Mukhtar and Singh, 2004). High positive genotypic correlation coefficient exist between days to maturity and 100 seed weight $\left(r_{g}=0.6958\right)$ implying that late maturing varieties tend to produce larger grains. This might be due to the higher photosynthetic efficiency of these varieties (Fagwalawa, 2005).

The high positive phenotypic and genotypic correlation coefficients observed between leaves per plant and fodder weight per plant $\left(r_{\mathrm{g}}=0.7815\right)$ suggested that the higher the number of leaves produced by a variety, the with Littleton et al., (1979) who reported that dry matheavier the fodder produced by such a variety. This agreed 
Tab. 2. Genotypic, phenotypic and environmental correlation coefficients for growth and yield components in 2004 wet season

\begin{tabular}{|c|c|c|c|c|c|c|c|c|c|c|c|c|}
\hline Character & & $\begin{array}{l}\text { Days to } \\
\text { mature }\end{array}$ & $\begin{array}{c}\text { Plant } \\
\text { height } \\
\text { (cm) }\end{array}$ & $\begin{array}{l}\text { Leaves } \\
\text { plant }^{-1}\end{array}$ & $\begin{array}{l}\text { Leaf } \\
\text { Area } \\
\left(\mathrm{cm}^{3}\right) \\
\end{array}$ & $\begin{array}{l}\text { Stem } \\
\text { Girth } \\
(\mathrm{cm})\end{array}$ & $\begin{array}{c}\text { Reaction } \\
\text { to virus }\end{array}$ & $\begin{array}{l}\text { Pod } \\
\text { plant }^{-1}\end{array}$ & $\begin{array}{l}\text { Seed } \\
\text { pod }^{-1}\end{array}$ & $\begin{array}{c}\text { Seed } \\
\text { weight } \\
(\mathrm{g})\end{array}$ & $\begin{array}{c}100 \text { seed } \\
\text { weight } \\
(\mathrm{g})\end{array}$ & $\begin{array}{c}\text { Fodder } \\
\text { weight } \\
(\mathrm{g})\end{array}$ \\
\hline \multirow{3}{*}{$\begin{array}{l}\text { Days to } \\
\text { flowering }\end{array}$} & $\mathrm{rg}$ & 0.9720 & 0.9113 & 0.8327 & 0.3694 & 0.6954 & 0.7253 & -0.6011 & -0.6159 & 0.1114 & 0.7622 & 0.9301 \\
\hline & $\mathrm{rp}$ & 0.9454 & 0.6820 & 0.8176 & 0.2732 & 0.5816 & 0.6050 & -0.5601 & -0.5485 & 0.1216 & 0.7315 & 0.8979 \\
\hline & re & -0.0122 & -0.1251 & 0.2310 & -0.0079 & 0.5169 & 0.1788 & 0.0969 & 0.1514 & 0.2956 & 0.1262 & 0.1895 \\
\hline \multirow{3}{*}{$\begin{array}{l}\text { Days to } \\
\text { maturity }\end{array}$} & $\mathrm{rg}$ & & 0.8945 & 0.7321 & 0.1422 & 0.5512 & 0.7993 & -0.5869 & -0.6756 & -0.0648 & 0.6958 & 0.8872 \\
\hline & $\mathrm{rp}$ & & 0.6856 & 0.7144 & 0.1468 & 0.4311 & 0.6482 & -0.5541 & -0.6342 & -0.0524 & 0.6771 & 0.8468 \\
\hline & re & & -0.0215 & -0.2196 & 0.0070 & 0.1668 & -0.0253 & 0.0234 & -0.3089 & 0.0396 & 0.2909 & -0.2156 \\
\hline \multirow{3}{*}{$\begin{array}{l}\text { Plant height } \\
(\mathrm{cm})\end{array}$} & $\mathrm{rg}$ & & & 0.8479 & 0.0601 & 0.4449 & 0.9944 & -0.1869 & -0.4061 & 0.3378 & 0.7597 & 0.7872 \\
\hline & $\mathrm{rp}$ & & & 0.6174 & -0.0615 & 0.0953 & 0.4269 & -0.1865 & -0.2440 & 0.2063 & 0.5862 & 0.5958 \\
\hline & re & & & -0.4499 & -0.2340 & -0.4116 & -0.5815 & -0.2585 & 0.1946 & -0.0630 & 0.0935 & 0.0054 \\
\hline \multirow{3}{*}{$\begin{array}{c}\text { Leaf per } \\
\text { plant }\left(\mathrm{cm}^{2}\right)\end{array}$} & $\mathrm{rg}$ & & & & 0.4809 & 0.6206 & 0.5968 & -0.3253 & -0.2528 & 0.4438 & 0.5898 & 0.8096 \\
\hline & $\mathrm{rp}$ & & & & 0.3888 & 0.4857 & 0.4960 & -0.2996 & -0.2319 & 0.3735 & 0.5599 & 0.7815 \\
\hline & re & & & & 0.3466 & 0.2049 & 0.1281 & 0.2377 & -0.0090 & -0.0980 & -0.2080 & -0.0062 \\
\hline \multirow{3}{*}{$\begin{array}{l}\text { Leaf area } \\
\left(\mathrm{cm}^{2}\right)\end{array}$} & $\mathrm{rg}$ & & & & & 0.9902 & -0.0140 & -0.4802 & -0.2892 & 0.6174 & 0.5311 & 0.5416 \\
\hline & $\mathrm{rp}$ & & & & & 0.6617 & 0.0230 & -0.3014 & -0.1950 & 0.3764 & 0.4297 & 0.3770 \\
\hline & re & & & & & 0.1796 & 0.0848 & 0.2343 & 0.0255 & -0.0770 & 02541 & -0.1362 \\
\hline \multirow{3}{*}{$\begin{array}{l}\text { Stem girth } \\
\quad(\mathrm{cm})\end{array}$} & $\mathrm{rg}$ & & & & & & 0.2911 & -0.7062 & -0.7107 & 0.4539 & 0.8125 & 0.8067 \\
\hline & $\mathrm{rp}$ & & & & & & 0.3157 & -0.5104 & -0.4599 & 0.4453 & 0.5780 & 0.5592 \\
\hline & re & & & & & & 0.3616 & 0.0204 & 0.1589 & 0.4489 & -0.1311 & -0.2583 \\
\hline \multirow{3}{*}{$\begin{array}{l}\text { Root length } \\
\quad(\mathrm{cm})\end{array}$} & $\mathrm{rg}$ & & & & & & 0.3928 & -0.2224 & -0.3425 & 0.8558 & 0.4803 & 0.5471 \\
\hline & $\mathrm{rp}$ & & & & & & 0.2933 & 0.0990 & -0.2020 & 0.5776 & 0.3330 & 0.3248 \\
\hline & re & & & & & & 0.1540 & 0.2653 & 0.0953 & -0.1531 & -0.0098 & -0.3630 \\
\hline \multirow{3}{*}{$\begin{array}{l}\text { Reaction } \\
\text { to virus }\end{array}$} & $\mathrm{rg}$ & & & & & & & -0.3855 & -0.5286 & 0.0909 & 0.7132 & 0.7288 \\
\hline & $\mathrm{rp}$ & & & & & & & -0.3268 & -0.3338 & 0.1029 & 0.5776 & 0.5673 \\
\hline & re & & & & & & & -0.1422 & 0.3075 & 0.1335 & 0.0683 & -0.1203 \\
\hline $\begin{array}{c}\text { Pod per } \\
\text { plant }\end{array}$ & rg & & & & & & & & 0.5837 & 0.2130 & -0.3018 & -0.4910 \\
\hline
\end{tabular}

ter production is dependent on leaf area with large number of produced when plants maintain relatively large and healthy leaf areas for long time. The negative and low association between leaf area and fodder weight with respect to the environment $(r=0.0062)$ further implied that the environment has less effect in the expression of these traits. Similarly, high but negative genotypic correlation coefficient existing between plant height and number of pod per plant $\left(\mathrm{r}_{\mathrm{g}}=0.6011\right)$ indicated that the variety with profuse vegetative growth habit e.g. 'Kanannado' produced less number of pods as earlier reported by Hadley et al. (1983). The moderate negative genotypic correlation coefficient $(\mathrm{r}=0.5869)$ and phenotypic correlation coefficient $\left(r_{p}=0.5541\right)$ observed between days to maturity and number of pod per plant, could be attributed to the poor performance of late maturing varieties included in the experiment (Rao, 1981).

\section{Conclusions}

Conclusively, the magnitude of genotypic correlation coefficients were in most cases higher than their corresponding phenotypic and environmental correlation coefficients. This showed that relationship between most of the traits studied where inherent and can be exploited in hybridization programmes to develop and select hybrids with superior characteristics.

\section{References}

Brazzino, A. L. (2002). Daily Trust of Tuesday, $4^{\text {th }}$ December, 2(85):127.

Ezeaku, I. E. and S. G. Mohammed (2006). Character association and path analysis in grain sorghum. African Journal of Biotechnology, 5 (14):337-1340.

Fagwalawa, L. D. (2005). Agrophysiological characterization of some early, medium and late maturing varieties of cowpea under sole and intercropping systems. Ph.D thesis. Department of Biological Sciences, Bayero University, Kano.

Hadley, P., E. H. Roberts, R. J. Summerfield and F. R. Minchin, (1983). A quantitative model of reproductive development in cowpea (Vigna unguiculata (L) Walp) in relation to photoperiod and temperature and implications for screening germplasm. Ann. Bot. 51:531-543.

Khairwal, I. S., K. N. Rai, D. J. Andrew and G. Harinarayana (1999). Pearl millet breeding. Oxford and H.B publishing 
128

company New Delhi P. 5-11.

Littleton, E. J., M. D. Dennet, J. Elston and J. L. Montelh (1979). The growth and development of cowpeas under tropical conditions. Journal of Agricultural Sciences (Camb) 93:292-307.

Martin, J. H., W. H. Leonard and D. L. Stamp (1976). Principle of field crop production, London, U.K, Collier Macmillan p.23-45.

Mukhtar, F. B. and B. B. Singh (2004). Growth response of photoperiod sensitive and photoperiod insensitive cowpea varieties to plant growth regulator treatments. Biological and Environmental Science Journal for the Tropics (BEST) $1(1) 79-86$.

Mukhtar, F. B. and B. B. Singh (2006). Influence of photoperiod and Gibberellic acid (GA3) on the growth and flowering of Cowpea (Vigna unguiculata (L) Walp). Journal of food, Agriculture and Environment Vol. 4(2):201-203.

Olofin, E. A (1987). Some aspects of the physical geography of the Kano region and related human responses. p.16-25.

Rachie, K. O. (1985). Introduction. In Cowpea, Research, Production and Utilization. John Wiley and Sons,
Chichester, UK, p. 21-26.

Rao, P. V. (1981). Genetic analysis of grain yield components in pearl millet (Pennisetum typhoides (Burm) 5 and JJ M. Sc. thesis Punjab Agricultural University, Lundhiana, India.

Singh, B. B. (1992). Improved local type cowpeas for the dry Savanna of northern Nigeria. Paper presented at the inhouse Review and Cropping Scheme Meeting of the Institute for Agricultural Research, Ahmadu Bello University Zaria Nigeria, pp. 1-8.

Singh, R. K. and B. D. Chaudhary (1985). Biomedical methods in Quantitative Genetic Analysis. Kalyani Publishers Ludhiana, India.

Singh, B. B., Mohan, D. R. Raj, K. E. Dashiell and L .E. N. Jackai (1997). Advances in Cowpea Research, IITA, Ibadan, Nigeria and Japan International Center for Agricultural Science. (JIRCAS). Tsukuba Ibaraki, Japan. Pp 240-247.

Steele, W. M. (1976). Cowpeas Vigna unguiculata, pp. $183-$ 185. In: Simmonds, N.W. (ed.) Evolution of Crop Plants. London, UK, Longmans.

Steel, R. G. and J. H. Torrie (1981). Principles and Procedures of Statistics. McGraw-Hill Book Co. New York. 